\title{
EFFECTS OF SHEAR WALLS ON A TYPICAL FOUR-STORY REINFORCED CONCRETE STRUCTURE SUBJECTED TO SEVERE EARTHQUAKE EVENTS
}

\author{
Nader Zad and Hani Melhem
}

Kansas State University, Ph.D., Department of Civil Engineering, Manhattan, Kansas, United States of America; naderzad@k-state.edu, melhem@k-state.edu

\begin{abstract}
Various seismic-resistant design methods are used to ensure the stability of multi-story buildings against lateral forces caused by earthquakes. Utilization of reinforced concrete shear walls is one of the most reliable methods of design and construction of earthquake-resistant buildings because it increases structural resistance to lateral loads and stiffens and strengthens the structure, thereby minimizing earthquake-induced damages. This paper investigates the beneficial effects of using shear walls in the structural design of a typical low-rise building to improve its resistance to earthquake events. To this end, a four-story reinforced concrete structure is modeled first without any shear walls, then with the addition to shear walls. The 2002 Denali Alaska earthquake is used as an example of a severe seismic excitation because it is considered the most massive strike-slip earthquake in North America in almost 150 year. SAP2000 is used to perform the dynamic analysis. In order to obtain an accurate representation of the structure's behavior, response modal nonlinear time-history dynamic analysis is utilized to analyze and compare the response of the building with and without shear walls. Study results showed that shear walls are very effective in achieving compliance with seismic design codes. In addition, the use of shear walls significantly reduces the shear stresses, bending moments, and displacements of the various members of the structure.
\end{abstract}

\section{KEYWORDS}

Modal, Nonlinear, Time history, Dynamic analysis, Denali, Reinforced concrete structure, Shear walls, SAP2000

\section{NTRODUCTION}

\section{General Excitation of an SDOF System}

The impulse response approach is used to solve for the response of an SDOF system to an arbitrary loading sequence, $F(t)$ :

$$
\begin{aligned}
& F(t)=m \ddot{x}+c \dot{x}+k x \\
& F(t)=P_{0} \sin (\Omega t) \\
& F(t)=P_{0} \sin (\Omega t+\phi)
\end{aligned}
$$

$k x \quad$ restoring pull of the spring

$c \dot{x} \quad$ damping force in the direction opposite to the direction of motion

$m \ddot{x} \quad$ intertidal force acting through the center of mass

$\dot{x} \quad$ velocity

$\ddot{x} \quad$ acceleration

$t \quad$ time 
$\Omega \quad$ frequency

$P_{0} \quad$ amplitude or maximum value of the force

$\phi \quad$ phase angle or phase lag

which represent the most general form of excitation. Such an arbitrary loading sequence can be approximated as a series of impacts [1].

\section{Excitation by Rigid Base Translation}

Base translation of the SDOF system is defined by the displacement $y(t)$, and the corresponding base acceleration is denoted by $\ddot{y}(t)$. The equilibrium equation for a damped SDOF system with rigid base translation $y(t)$ can be expressed as [1]

$$
m(\ddot{x}+\ddot{y})+c \dot{x}+k x=0
$$

\section{Building Components and Numerical Modeling}

When building a numerical model of a structure slabs are typically modeled using shell elements while shear walls are modeled using plate elements since out-of-plane bending is insignificant for walls. Interior walls may be non-load-bearing partition walls or load-bearing walls that must carry the floor loads and act as shear walls to resist lateral forces [2].

\section{Load-Bearing Walls}

Bearing walls potentially act as shear walls as they carry roof and floor loads as well as the weight of overhead walls. As exterior walls, load-bearing walls also must perform as curtain walls to resist lateral wind pressure in slab action.

Vertical structural planes in a building are connected by horizontal floor planes, and external and internal lateral forces are distributed along the floor structures, which act as deep horizontal beams, to the vertical shear walls. The shear walls, which can be arranged in a variety of ways, carry lateral loads to the foundation and to the ground. Common bearing wall structures include the following [2]:

- Plain or reinforced masonry walls (e.g., brick, concrete block)

- Cast-in-place concrete walls

- Precast concrete walls

- Framed walls (e.g., stud walls, tubular structures)

- Trussed walls (e.g., traditional half-timber construction in Europe, brace-framed tubes, latticed tubes)

\section{Wall Proportion and Shear Wall Behavior}

The wall proportion, height/width $(\mathrm{H} / \mathrm{W})$ ratio, of rectangular shear walls ranges from low-rise (low/long) walls to slender high-rise (tall) walls. Tall shear walls typically deform in the bending mode, allowing shear deformation to be ignored. However, shear deformations control low shear walls with approximately $\mathrm{H} / \mathrm{B}<1$. The wall proportion significantly influences shear wall behavior in the following ways:

- Long shear walls with lengths at least approximately three times longer than their heights, $\mathrm{H} / \mathrm{B} \leq 0.33$, represent shear panels controlled by shear deflections; in other words, shear panels wrack linearly with distortion similar to a parallelogram.

- Slender shear walls with heights at least approximately three times higher than their widths, $H / B \geq 3$, exhibit shallow beam behavior similar to vertical cantilever beams controlled primarily by flexural deflections. 
- Intermediate shear walls, approximately $3>\mathrm{H} / \mathrm{B}>0.33$, represent deep beam behavior, with a transition stage from the long to the slender wall or from the shear cantilever to the flexural cantilever.

In low-rise buildings, openings may penetrate walls, causing slender piers to act as flexural cantilevers under lateral shear wracking.

Long and intermediate concrete walls usually have relatively light reinforcement, with the exception of additional vertical bars at wall boundaries and around openings and additional horizontal bars at the floor levels.

Although the walls in bearing-wall structures are typically load-bearing to support floor loads, they can also act as shear walls to resist lateral forces due to wind and earthquakes. Shear walls in masonry buildings usually intersect with other walls, resulting in single or double returns at the ends of the walls. With respect to lateral force action, shear walls can act as vertical cantilever plate girders over the full building height, with walls representing a web, floors representing web stiffeners, and end returns representing flanges. The flanges are assumed to carry only axial forces due to cantilever bending, and the web is expected to carry all the shear [2].

\section{Openings in Shear Walls}

Small openings do not influence behavior of a shear wall, but a wall with larger openings is modeled as a pier/spandrel system. A wall with very large openings, however, converts to a frame, thereby exhibiting frame behavior [2].

\section{Modeling Walls with Frame Elements}

Since walls behave similarly to trusses, a truss model may be used to visualize force flow in concrete and masonry shear walls. The truss model can approximate the behavior of a shear wall because it assumes that the vertical elements provide axial-flexural resistance and the diagonal members provide shear resistance [2].

\section{Shear Wall-Frame Interaction}

Shear walls and frames typically interact in braced skeleton buildings. Interaction may include the following:

- Shear walls that resist all lateral forces stabilize hinged frames that carry only gravity loads.

- Similar to compressive struts, infill panels brace rigid frames. Beams, columns, and walls in the frame provide maximum stiffness to the system

- Rigid frames are hinged to or continuously connected to shear walls so that shear walls and frames both resist lateral forces.

Interactive behavior of the rigid frame-shear wall structure depends on the relative stiffness of the frame and the stiffness of the shear walls. For example, shear walls in a tower structure with a large central core and widely spaced perimeter columns may provide $90 \%$ of the lateral stiffness. In general, however, shear walls provide most lateral resistance only for buildings of moderate height or the bottom portion of tall buildings. In addition, resulting stiffness of the combined structure of frames and shear walls is considerably higher than the sum of its components. Frame shear deformation and bending deflection of the wall in tall buildings results in a flat S-curve, as if a shearframe building sits on top of a flexural cantilever structure.

In this study, membrane elements are utilized to model shear walls when the beams are hinged to the shear wall and when the shear walls are fill-in panels that provide full continuity with beams and columns. Shell elements are used when moment continuity with beams is required [2].

\section{Vertical Lateral Force-Resisting Structures}

Although wind pressure and seismic excitation cause primary lateral loads, lateral soil and liquid pressures as well as gravity loads in cantilevering structures and irregular structures can cause 


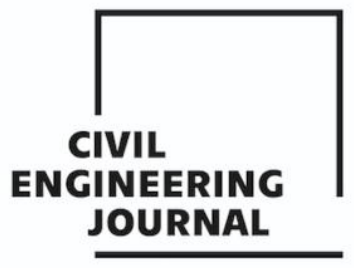

Article no. 60

THE CIVIL ENGINEERING JOURNAL 4-2021

lateral loads. Vertical lateral force-resisting structures such as moment-resisting frames, braced frames, shear walls, and dual systems (e.g., shear wall and frames) typically resist these loads.

A frame braced by trussing or shear walls is relatively stiffer than only a frame in which lateral deflection depends on the rigidity of beam-column and slab joints [2].

\section{Bearing Wall Systems}

Examples of bearing wall systems include load-bearing shear walls, such as reinforced or plain concrete shear walls (ordinary, special) and reinforced or plain masonry shear walls (ordinary, special), and light frame walls with shear panels [2].

Tall buildings respond to lateral load action as flexural cantilevers if the resisting structure consists of shear walls or a braced frame, whereas rigid frame structures and massive buildings respond as shear cantilevers. The combined action of different structure systems for tall buildings, such as rigid frame shear wall interaction, may have the appearance of a flat S-curve [2].

\section{SUMMARY OF COMPARABLE RESEARCH LITERATURE}

Bhat et al. used STAAD Pro to compare earthquake responses of buildings with and without shear walls [3]. Chandurkar et al. determined the optimal location for shear walls in a multi-storied building and studied shear wall effectiveness using four models [4]. Kurma et al. conducted pushover analysis on two multi-storied Reinforced Concrete (R.C.) frame buildings: one building had 10 stories with five bays in $X$ direction and five bays in $Y$ direction, and the second building contained 15 stories. The shear wall was used to study their resisting lateral forces, and the paper highlighted the effect of a shear wall on the building when a wall was located along the long as well as the short sides of the building [5]. Tidke et al. used five models to study the effect of seismic loading relative to shear wall placement in various locations in a building [6]. Sanjeev et al. considered a spatial configuration of a 20-storied structure with a maximum $70 \mathrm{~m}$ height, and each story height of $3.5 \mathrm{~m}$ with a shear wall and bracing at various locations in the building [7].

\section{EXPERIMENTAL STUDY}

\section{Seismic Excitation}

The novelty of this paper and research is a realistic application that considers an actual seismic excitation record (2002 Denali Alaska earthquake) that was the strongest ever recorded in the interior of Alaska happened in the United States of America. The authors consider this to be a meaningful contribution to the state of knowledge. The Denali fault event was felt as far as Washington and caused seiches in pools and lakes as far as Texas and Louisiana. "The earthquake was associated with 340 kilometers of surface rupture and was the most massive strike-slip earthquake in North America in almost 150 years" [8]. The other scholars and researchers reviewed referenced in the literature review section of the paper did not consider an actual seismic record for their analysis, especially earthquakes that happened in the United States. Updates and enhancement of the building codes normally consider results of this nature to modify the design requirements and recommendations.

"The estimated magnitude of this earthquake ranges from the body wave magnitude of 7.0 to the moment magnitude (MW) of 7.9 to the surface wave magnitude of 8.5 . While the fault rupture lasted for about 100 seconds from its initiation to the arrest, its distal effects were felt for many days. There were reports of triggered seismicity in volcanic and geothermal centers in Washington and California and regional seismicity in Utah" [9].

\section{Building Description}


The building in this study was a four-storied concrete shear wall building with concrete flat slabs supported by concrete columns. Figure 1 shows the floor and roof plan.

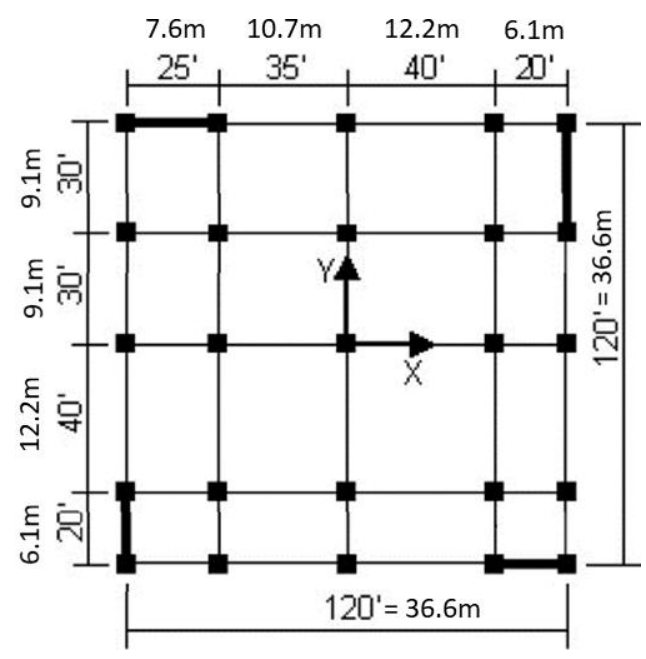

Fig. 1 - Building Floor and Roof Plan

Based on Zad et al. research paper, one of the best locations of shear walls is on the structure's perimeter at the left of each of the four building faces. They showed in their research that using shear walls on those locations will significantly improve structural behavior [10]. The authors had investigated the effects of shear wall locations in a different published paper [10].

The steel properties used in this study were as follows:

- $E=29,000 \mathrm{ksi}=199947961.12 \mathrm{KN} / \mathrm{m}^{2}$

- Poisson's ratio $=0.3$

The concrete properties were as follows:

- $E=3600 \mathrm{ksi}=24821126.208 \mathrm{KN} / \mathrm{m}^{2}$

- Poisson's ratio $=0.2$

- Weight per unit volume is $0.15 \mathrm{kip} / \mathrm{ft}^{3}=23.56 \mathrm{~N} / \mathrm{m}^{3}$

The members geometric properties were as follows:

- Walls are $12 \mathrm{in.}(30.48 \mathrm{~cm})$ thick.

- Columns are 20 in. $\times 20$ in. $(50.8 \times 50.8 \mathrm{~cm})$

- Size of beams is 12 in. $\times 18$ in. $(30.48 \times 45.72 \mathrm{~cm})$

- Floors and roof are $10 \mathrm{in} .(25.4 \mathrm{~cm})$ thick flat slabs.

The assumptions used here are that the diaphragms are rigid in plane, and the columns are fixed base. Figure 2 shows a three-dimensional (3-D) perspective of the building model.

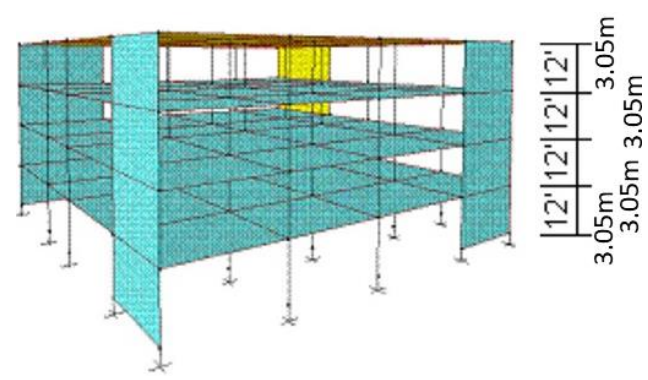

Fig. 2 - 3D Perspective 
CIVIL

ENGINEERING JOURNAL

The roof and floors are shell-thin members. Figure 3 shows the reinforced concrete sections for the columns.

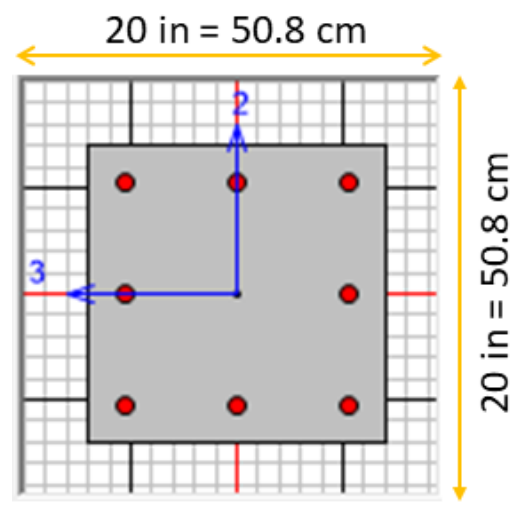

Fig. 3 - Columns' sections

The time history files Anchorage-1 (earthquake station) in the $X$ direction and Anchorage-2 (earthquake station) in the $Y$ direction were applied to the structure. Each time history was given in units of $\mathrm{g}$, with 34,400 time steps at equal spacings of 0.005 second for a total of 172 seconds. Each line in the time history files contained five accelerations points.

Figure 4 shows the unscaled response spectra.

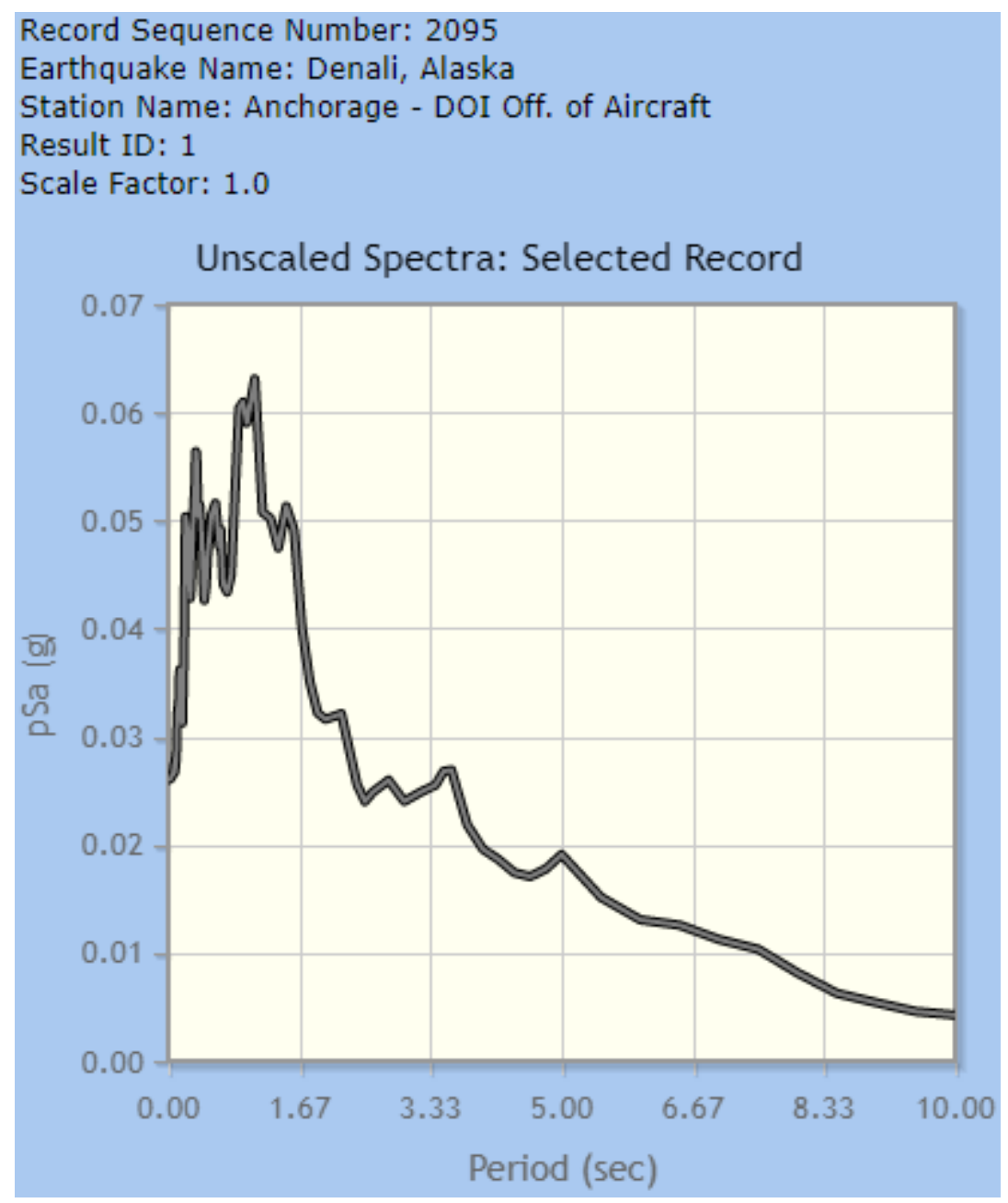

Fig. 4 - Unscaled Response Spectra 
In general, an accelerogram that measures peak ground acceleration, duration, and frequency content of an earthquake can be integrated to obtain time variations of ground velocity and ground displacement [10].

\section{NUMERICAL COMPARISON}

Figure 5 demonstrates the unscaled time series of the Denali earthquake record (Horizontal1 Component).

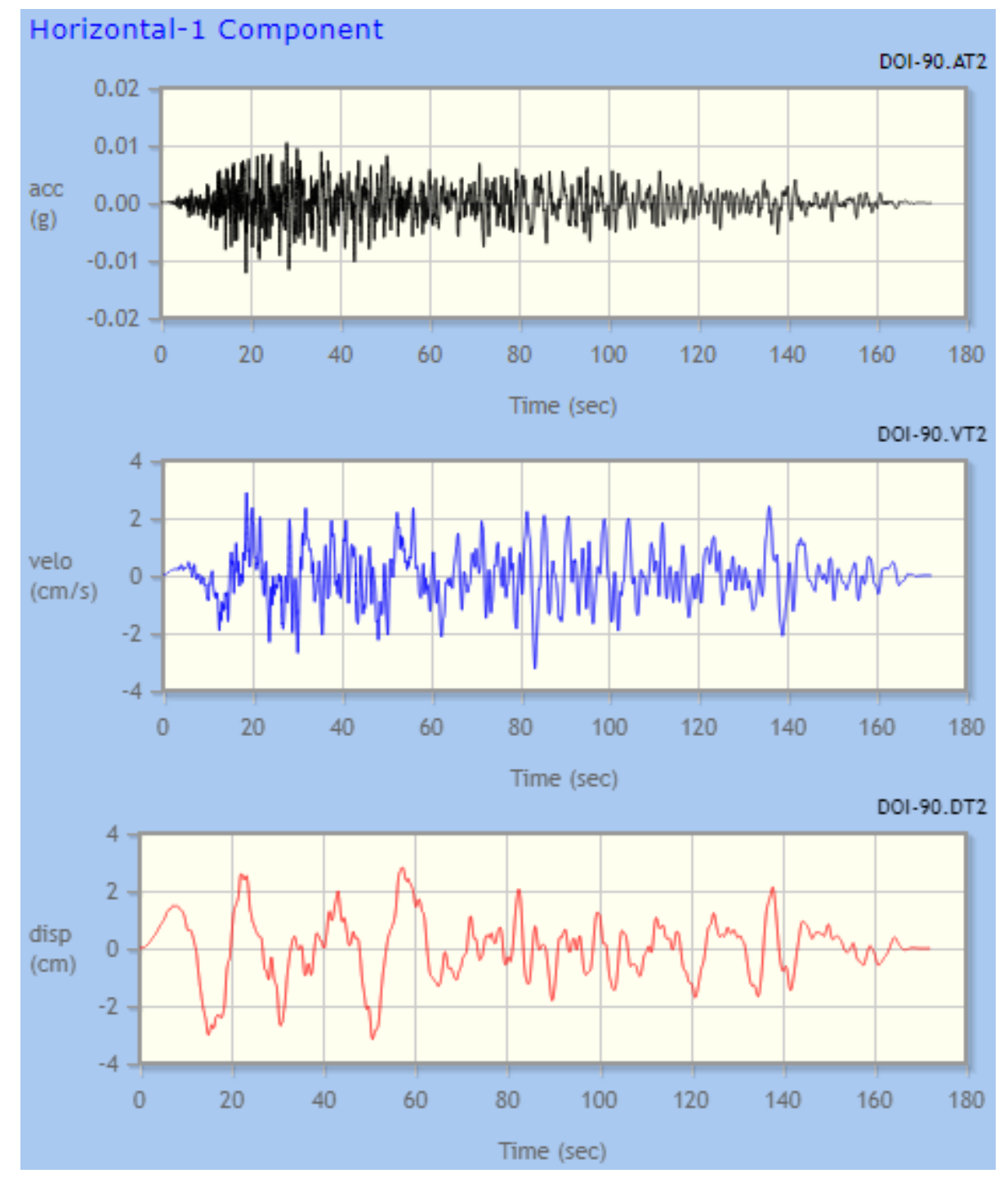

Fig. 5 - Acceleration-Time, Velocity-Time, and Displacement-Time Graphs ("Anchorage - DOI Off. of Aircraft" Record of 3 November 2002, Denali Earthquake) (Horizontal- 1 Component) $\left(90^{\circ}\right.$ )

Figure 6 demonstrates the unscaled time series of the Denali earthquake record (Horizontal2 Component). 


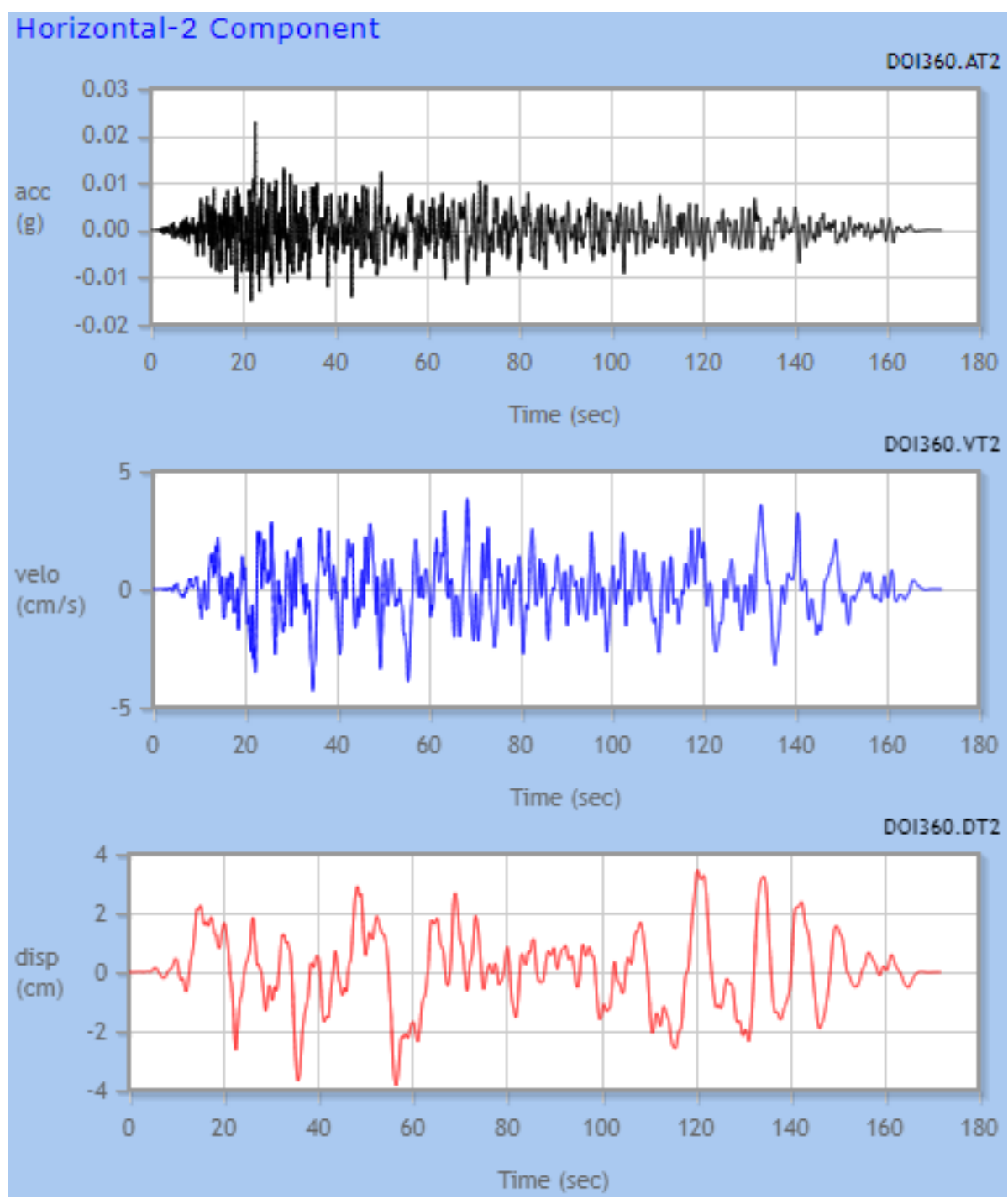

Fig. 6 - Acceleration-Time, Velocity-Time, and Displacement-Time Graphs ("Anchorage - DOI Off. of Aircraft" Record of 3 November 2002, Denali Earthquake) (Horizontal-2 Component) $\left(360^{\circ}\right)$

Figure 7 demonstrates the unscaled time series of the Denali earthquake record (Vertical Component). 


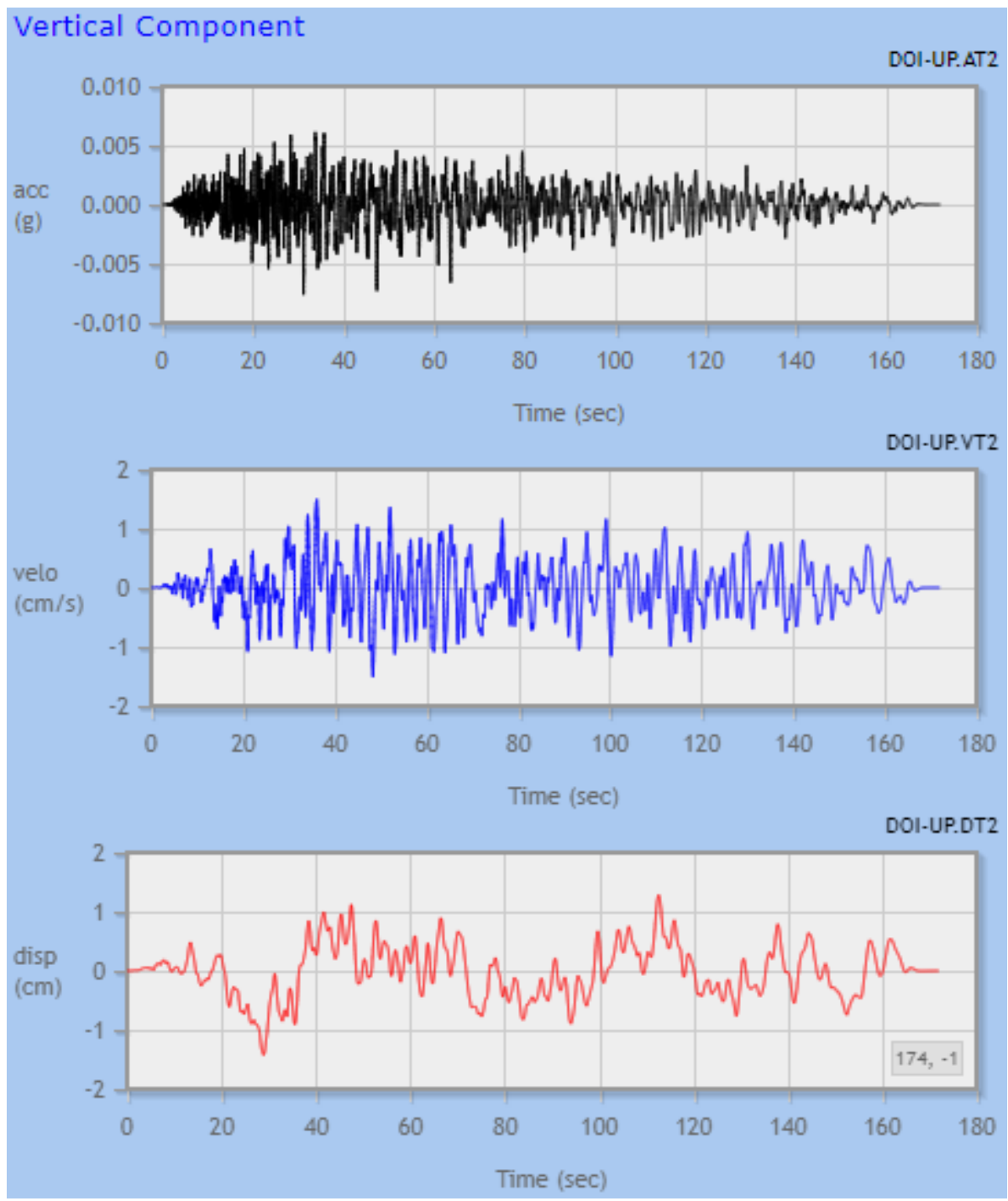

Fig. 7 - Acceleration-Time, Velocity-Time, and Displacement-Time Graphs ("Anchorage - DOI Off. of Aircraft" Record of 3 November 2002, Denali Earthquake) (Vertical Component)

Figures 8 and 9 show load time histories (function graphs in the $X$ and $Y$ direction) of Anchorage-1.TH and Anchorage-2.TH, respectively. 
Article no. 60

CIVIL

ENGINEERING JOURNAL

II Display Plot Function Traces (Anchorage)

$\times$

File
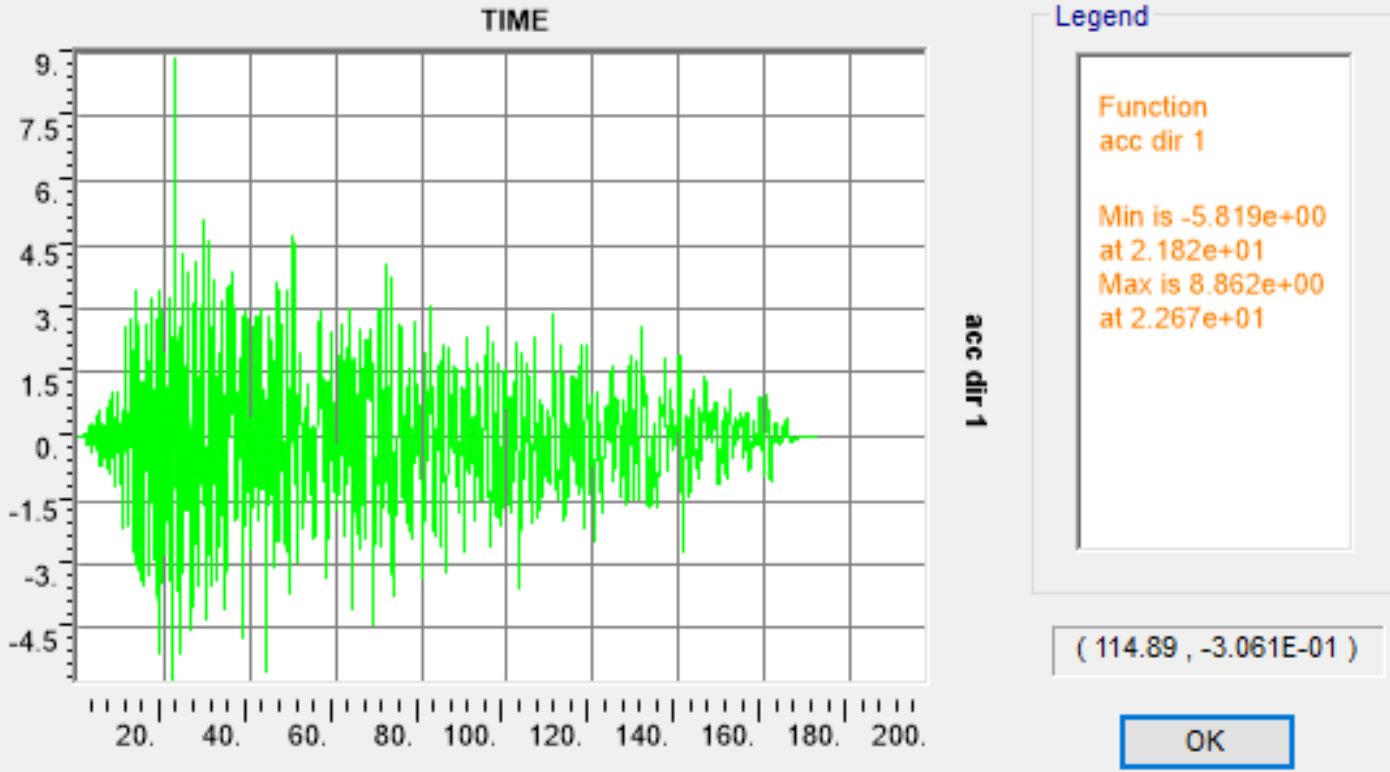

Fig. 8 - Time History Function Graph, X Direction

2 Display Plot Function Traces (Anchorage)

File
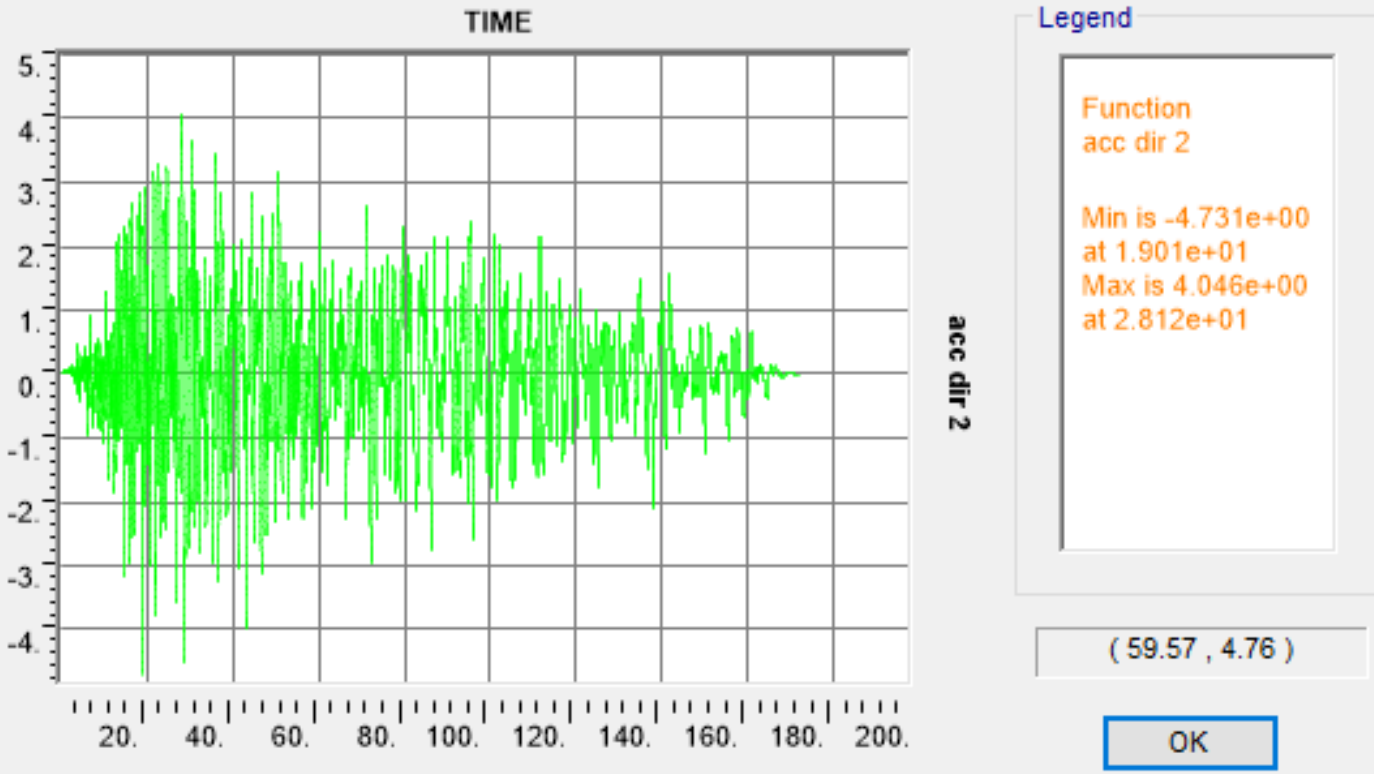

Fig. 9 - Time History Function Graph, Y Direction 
Article no. 60

CIVIL

ENGINEERING

JOURNAL

\section{RESULTS}

Figure 10 depicts the isometric (3-D) and the two-dimensional (2-D) views of the structure withoutany shear walls, and Figure 11 shows the deformed shape of this study's building without any shear walls.
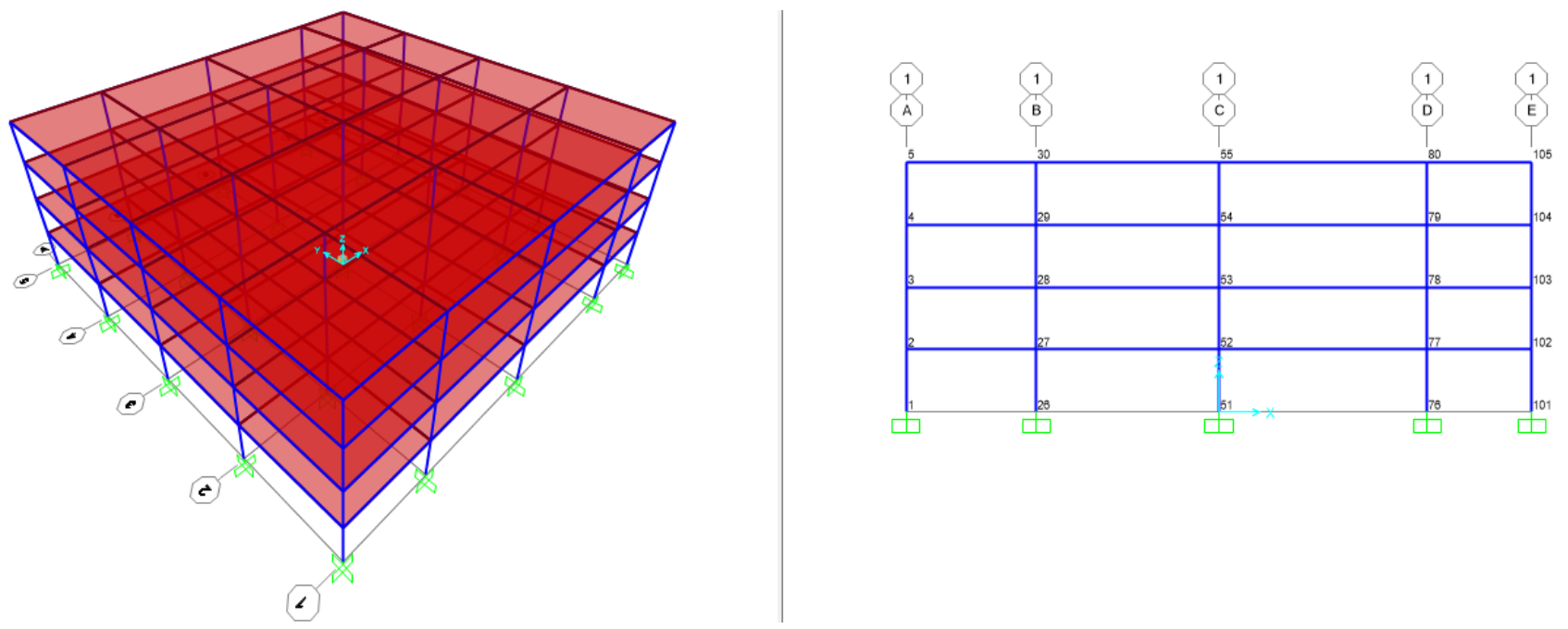

Figure 10 - 3-D and 2-D Views without any Shear Walls
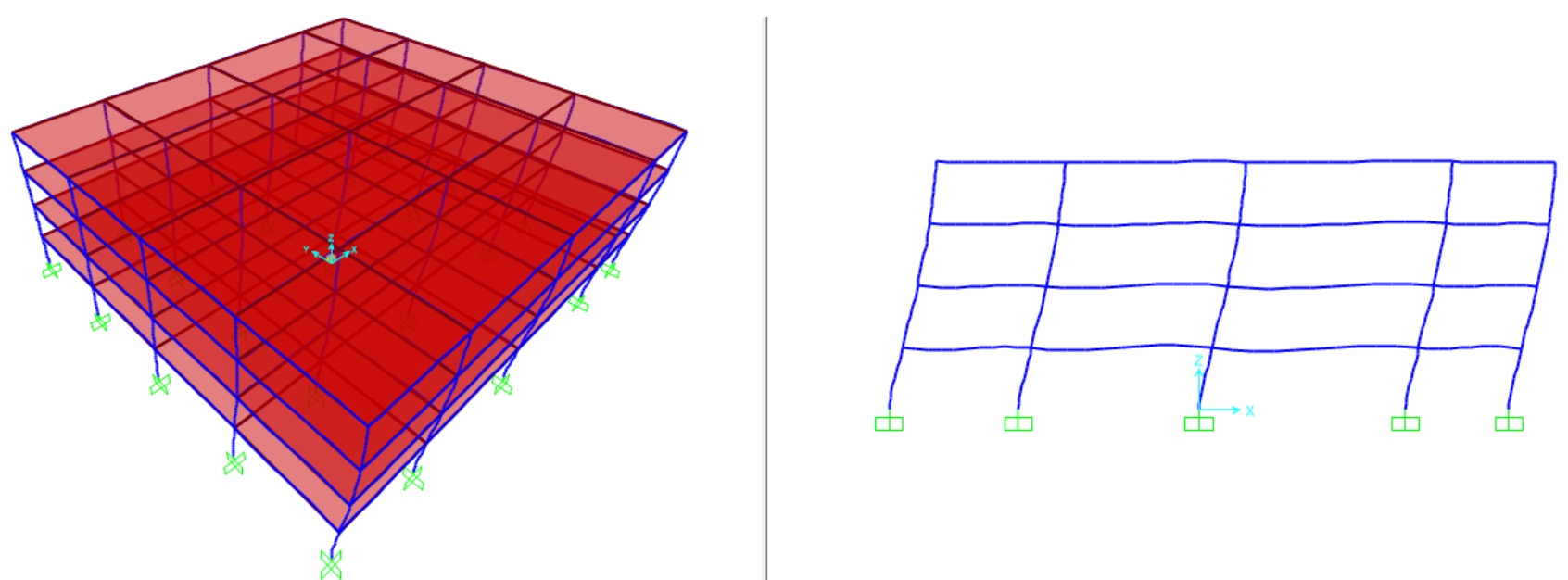

Fig. 11 - Deformed Shape of Building without any Shear Walls

Figure 12 depicts the isometric (3-D) and the two-dimensional (2-D) views of the structure with shear walls, and Figure 13 shows the deformed shape of this study's building with shear walls. 

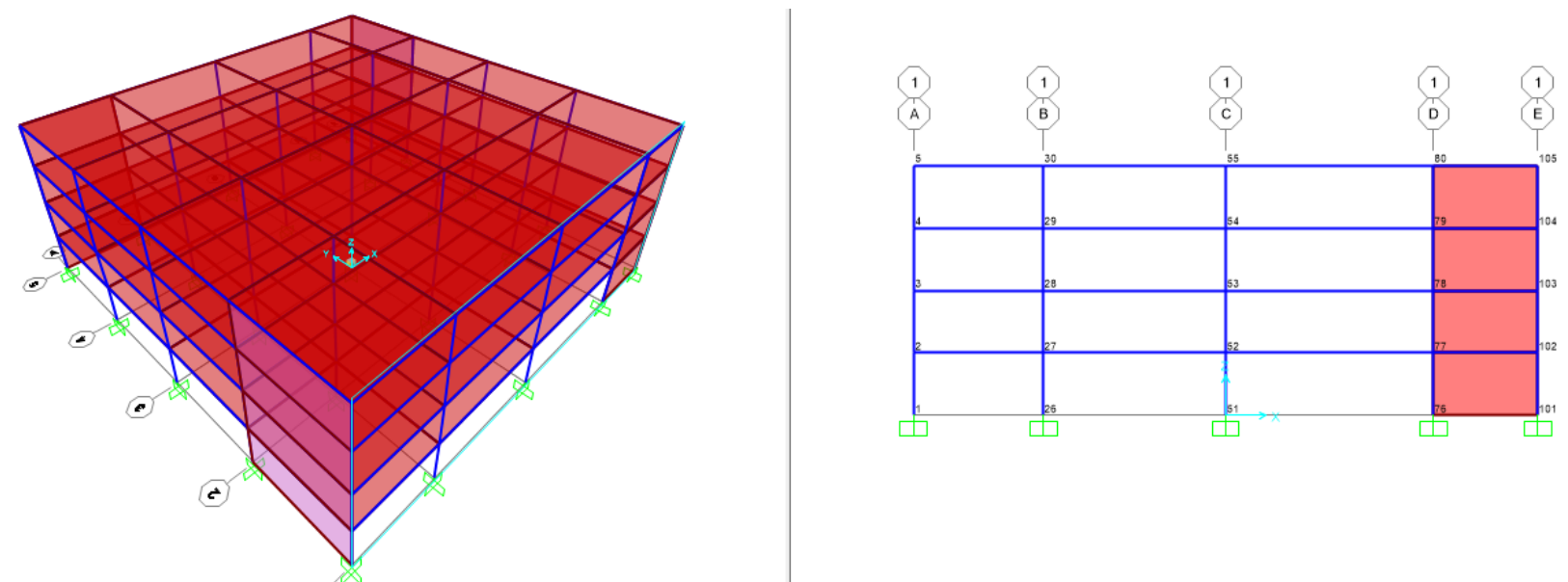

Figure 12 - 3-D and 2-D views with shear walls
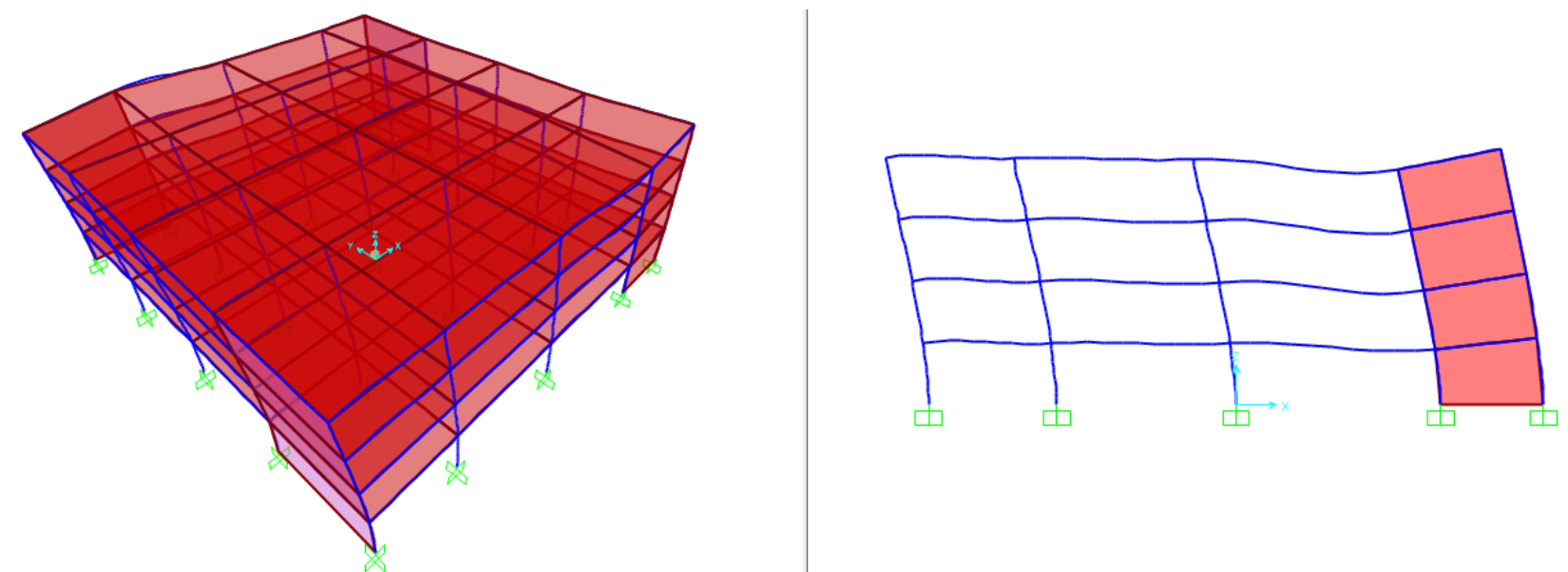

Fig. 13 - Deformed Shape of Building with Shear Walls

Tables 1 through 7 compare the data and results of nonlinear time history analysis of the structure without shear versus those of the structure with shear walls.

Tab. 1 - Structural time period for nonlinear time history analysis without and with shear walls

\begin{tabular}{|c|c|c|c|}
\hline & Without shear walls & With shear walls & Effect of shear walls \\
\hline Mode 1 & $0.90432 \mathrm{~s}$ & $0.32854 \mathrm{~s}$ & $63.67 \%$ decrease \\
\hline Mode 2 & $0.88607 \mathrm{~s}$ & $0.25011 \mathrm{~s}$ & $71.77 \%$ decrease \\
\hline Mode 3 & $0.82213 \mathrm{~s}$ & $0.18912 \mathrm{~s}$ & $84.29 \%$ decrease \\
\hline Mode 4 & $0.29430 \mathrm{~s}$ & $0.11885 \mathrm{~s}$ & $59.61 \%$ decrease \\
\hline Mode 5 & $0.28930 \mathrm{~s}$ & $0.11685 \mathrm{~s}$ & $59.6 \%$ decrease \\
\hline
\end{tabular}


Article no. 60

CIVIL

ENGINEERING

THE CIVIL ENGINEERING JOURNAL 4-2021

Tab. 2 - Structural frequency for nonlinear time history analysis without and with shear walls

\begin{tabular}{|c|c|c|c|}
\hline & Without shear walls & With shear walls & Effect of shear walls \\
\hline Mode 1 & $1.10580 \mathrm{~Hz}$ & $3.04376 \mathrm{~Hz}$ & $175.25 \%$ increase \\
\hline Mode 2 & $1.12857 \mathrm{~Hz}$ & $3.99809 \mathrm{~Hz}$ & $254.26 \%$ increase \\
\hline Mode 3 & $1.21634 \mathrm{~Hz}$ & $5.28750 \mathrm{~Hz}$ & $334.70 \%$ increase \\
\hline Mode 4 & $3.39780 \mathrm{~Hz}$ & $8.41340 \mathrm{~Hz}$ & $147.61 \%$ increase \\
\hline Mode 5 & $3.45652 \mathrm{~Hz}$ & $8.55775 \mathrm{~Hz}$ & $147.58 \%$ increase \\
\hline
\end{tabular}

Tab. 3 - Design base shear for nonlinear time history analysis without and with shear walls

\begin{tabular}{|c|c|c|c|}
\hline & Without shear walls & With shear walls & Effect of shear walls \\
\hline in $X$ direction & $\begin{array}{c}\text { 703.747 Kip = } \\
3130.42 \mathrm{KN}\end{array}$ & $\begin{array}{c}1022.912 \mathrm{Kip}= \\
4550.14 \mathrm{KN}\end{array}$ & $45.35 \%$ increase \\
\hline in $Y$ direction & $\begin{array}{l}\text { 595.104 Kip }= \\
2647.15 \mathrm{KN}\end{array}$ & $\begin{array}{c}795.795 \mathrm{Kip}= \\
\text { 3539.87 KN }\end{array}$ & $33.72 \%$ increase \\
\hline
\end{tabular}

Tab. 4 - Base moment for nonlinear time history analysis without and with shear walls

\begin{tabular}{|c|c|c|c|}
\hline & Without shear walls & With shear walls & Effect of shear walls \\
\hline in $X$ direction & $\begin{array}{c}19879.1282 \mathrm{Kip}-\mathrm{ft}= \\
26952.5 \mathrm{KN}-\mathrm{m}\end{array}$ & $\begin{array}{c}30284.2814 \mathrm{Kip}-\mathrm{ft}= \\
41059.9618 \mathrm{KN}-\mathrm{m}\end{array}$ & 52.34\% increase \\
\hline in $Y$ direction & $\begin{array}{c}-23330.7542 \mathrm{Kip}-\mathrm{ft}= \\
-31632.2472 \mathrm{KN}-\mathrm{m}\end{array}$ & $\begin{array}{c}-38160.8949 \mathrm{Kip}-\mathrm{ft}= \\
-51739.2131 \mathrm{KN}-\mathrm{m}\end{array}$ & $63.56 \%$ increase \\
\hline
\end{tabular}

Tab. 5 - Maximum displacements for nonlinear time history analysis without and with shear walls

\begin{tabular}{|c|c|c|c|}
\hline & Without shear walls & With shear walls & Effect of shear walls \\
\hline Max UX for Joint 52 & $\begin{array}{c}-1.62891 \mathrm{in.}= \\
-4.13743 \mathrm{~cm}\end{array}$ & $\begin{array}{c}-1.52704 \mathrm{in.}= \\
-3.87868 \mathrm{~cm}\end{array}$ & $6.25 \%$ decrease \\
\hline Max UY for Joint 52 & $\begin{array}{c}-1.28192 \mathrm{in.}= \\
-3.25607 \mathrm{~cm}\end{array}$ & $\begin{array}{c}-1.24967 \mathrm{in.}=- \\
3.17416 \mathrm{~cm}\end{array}$ & $2.51 \%$ decrease \\
\hline Max UX for Joint 53 & $\begin{array}{c}-1.88686 \mathrm{in} .= \\
-4.79262 \mathrm{~cm}\end{array}$ & $\begin{array}{c}-1.57223 \mathrm{in} .= \\
-3.99346 \mathrm{~cm}\end{array}$ & $16.67 \%$ decrease \\
\hline Max UY for Joint 53 & $-1.32037 \mathrm{in.}=$ & $\begin{array}{c}-1.25751 \mathrm{in} .= \\
-3.19407 \mathrm{~cm}\end{array}$ & $4.76 \%$ decrease \\
\hline
\end{tabular}


Article no. 60

CIVIL

ENGINEERING

THE CIVIL ENGINEERING JOURNAL 4-2021

\begin{tabular}{|c|c|c|c|}
\hline Max UX for Joint 54 & $\begin{array}{c}-2.08840 \mathrm{in.}= \\
-5.304536 \mathrm{~cm}\end{array}$ & $\begin{array}{l}-1.62858 \mathrm{in.}= \\
-4.13659 \mathrm{~cm}\end{array}$ & $22.01 \%$ decrease \\
\hline Max UY for Joint 54 & $\begin{array}{c}1.43210 \mathrm{in.}= \\
3.63753 \mathrm{~cm}\end{array}$ & $\begin{array}{l}-1.2662 \mathrm{in.}= \\
-3.2161 \mathrm{~cm}\end{array}$ & $11.58 \%$ decrease \\
\hline Max UX for Joint 65 & $\begin{array}{c}-2.22948 \mathrm{in} .= \\
-5.66287 \mathrm{~cm}\end{array}$ & $\begin{array}{l}-1.65246 \mathrm{in.}= \\
-4.19724 \mathrm{~cm}\end{array}$ & $25.88 \%$ decrease \\
\hline Max UY for Joint 65 & $\begin{array}{l}1.49782 \mathrm{in.}= \\
3.80446 \mathrm{~cm}\end{array}$ & $\begin{array}{c}-1.27455 \mathrm{in} .=- \\
3.23735 \mathrm{~cm}\end{array}$ & $14.9 \%$ decrease \\
\hline
\end{tabular}

Note: Joints 52, 53, 54, and 65 are the center joints on the first, second, third, and forth floor, respectively

Tab. 6 - Drifts for nonlinear time history analysis without and with shear walls

\begin{tabular}{|c|c|c|c|}
\hline & Without shear walls & With shear walls & Effect of shear walls \\
\hline $1^{\text {st }}$ Floor - $X$ direction & $\begin{array}{l}0.01131 \mathrm{in} .= \\
0.287274 \mathrm{~mm}\end{array}$ & $\begin{array}{c}0.0106 \text { in. }=0.2692 \\
\mathrm{~mm}\end{array}$ & $6.25 \%$ decrease \\
\hline $1^{\text {st }}$ Floor - $Y$ direction & $\begin{array}{c}0.0089 \text { in. }=0.226 \\
\mathrm{~mm}\end{array}$ & $\begin{array}{l}0.00867 \mathrm{in} .= \\
0.22021 \mathrm{~mm}\end{array}$ & $2.51 \%$ decrease \\
\hline $2^{\text {nd }}$ Floor - $X$ direction & $\begin{array}{l}0.00179 \mathrm{in} .= \\
0.04546 \mathrm{~mm}\end{array}$ & $\begin{array}{l}0.00031 \mathrm{in} .= \\
0.00787 \mathrm{~mm}\end{array}$ & $82.52 \%$ decrease \\
\hline $2^{\text {nd }}$ Floor - $Y$ direction & $\begin{array}{c}0.00026 \mathrm{in} .=0.0066 \\
\mathrm{~mm}\end{array}$ & $\begin{array}{l}0.00005 \mathrm{in.}= \\
0.00127 \mathrm{~mm}\end{array}$ & $79.69 \%$ decrease \\
\hline $3^{\text {rd }}$ Floor - $X$ direction & $\begin{array}{c}0.00139 \mathrm{in.}=0.0353 \\
\mathrm{~mm}\end{array}$ & $\begin{array}{c}0.00039 \text { in. }=0.0099 \\
\mathrm{~mm}\end{array}$ & $72.05 \%$ decrease \\
\hline $3^{\text {rd }}$ Floor - $Y$ direction & $\begin{array}{l}0.00077 \text { in. = } \\
0.01955 \mathrm{~mm}\end{array}$ & $\begin{array}{l}0.00006 \mathrm{in.}= \\
0.00152 \mathrm{~mm}\end{array}$ & $92.25 \%$ decrease \\
\hline $4^{\text {th }}$ Floor $-X$ direction & $\begin{array}{l}0.00097 \mathrm{in.}= \\
0.02463 \mathrm{~mm}\end{array}$ & $\begin{array}{l}0.00016 \mathrm{in} .= \\
0.00406 \mathrm{~mm}\end{array}$ & $83.14 \%$ decrease \\
\hline $4^{\text {th }}$ Floor $-Y$ direction & $\begin{array}{l}0.00045 \text { in. }= \\
0.01143 \mathrm{~mm}\end{array}$ & $\begin{array}{l}0.00005 \mathrm{in} .= \\
0.00127 \mathrm{~mm}\end{array}$ & $87.28 \%$ decrease \\
\hline Total drift - $X$ direction & $\begin{array}{l}0.00387 \mathrm{in} .= \\
0.09829 \mathrm{~mm}\end{array}$ & $\begin{array}{l}0.00286 \text { in. }= \\
0.07264 \mathrm{~mm}\end{array}$ & $25.89 \%$ decrease \\
\hline Total drift- $Y$ direction & $\begin{array}{c}0.0026 \text { in. }=0.066 \\
\mathrm{~mm}\end{array}$ & $\begin{array}{l}0.00221 \mathrm{in} .= \\
0.05613 \mathrm{~mm}\end{array}$ & $14.92 \%$ decrease \\
\hline
\end{tabular}

Tab. 7 - Total weight of building for nonlinear time history analysis without and with shear walls

\begin{tabular}{|l|c|c|c|}
\hline & Without shear walls & With shear walls & Effect of hear walls \\
\hline Total weight of building & $\begin{array}{c}9700 \mathrm{Kip}=43147.74 \\
\mathrm{KN}\end{array}$ & $\begin{array}{c}10456 \mathrm{Kip}= \\
46510.605 \mathrm{KN}\end{array}$ & $7.79 \%$ increase \\
\hline
\end{tabular}




\section{Interpretation of the Results}

Tables 1 and 2 indicate that adding shear walls to the structure leads to a decrease of the structural time period ranging between nearly $59.6 \%$ and $84.3 \%$, corresponding to an increase of the structure frequency ranging between approximately $148 \%$ and $255 \%$.

As shown in Tables 3 and 4, shear walls result in the increase of the design base shear (45.35\% in the $X$ direction and $33.72 \%$ in the $Y$ direction), and the base moment $(52.34 \%$ in the $X$ direction and $63.56 \%$ in the $Y$ direction). Such increases will lead to a safer and more conservative design.

As it can be seen in Tables 5 and 6, the horizontal displacements and the inter-story drifts are significantly decreased when the shear walls are added. This data comparison is better represented in Figure 14 which charts in a bar graph to provide a clear understanding of the displacement of each floor in $X$ and $Y$ directions with and without any shear walls, and in Figure 15 which charts the drifts of various stories of the building. The addition of the shear walls causes a decrease in the joints maximum horizontal displacement in the $X$ direction that ranges between $6.25 \%$ and $25.88 \%$, and a decrease in joint maximum horizontal displacement in the $Y$ direction ranging from $2.51 \%$ to $14.9 \%$. Also, the decrease in floor drifts of the structure in the $X$ direction ranges from $6.25 \%$ to $83.14 \%$, and in the $Y$ direction from $2.51 \%$ to $92.25 \%$. These are considered significant improvements to the structure performance during such a powerful earthquake.

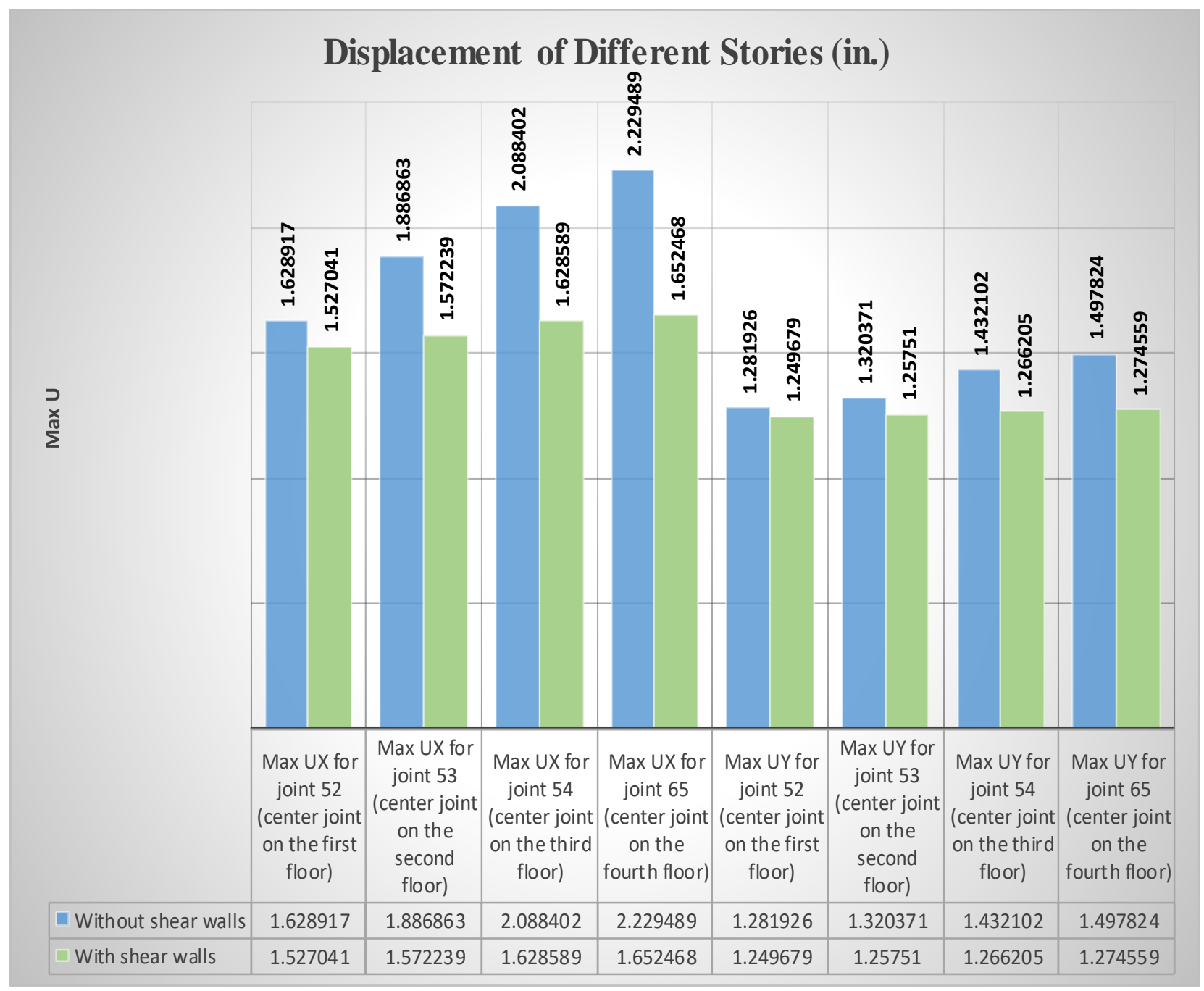




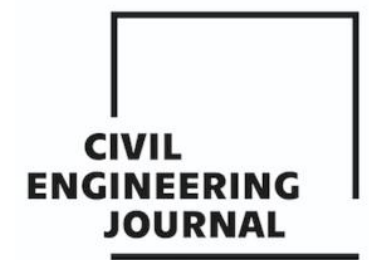

Article no. 60 THE CIVIL ENGINEERING JOURNAL 4-2021

Fig. 14 - Story Displacements

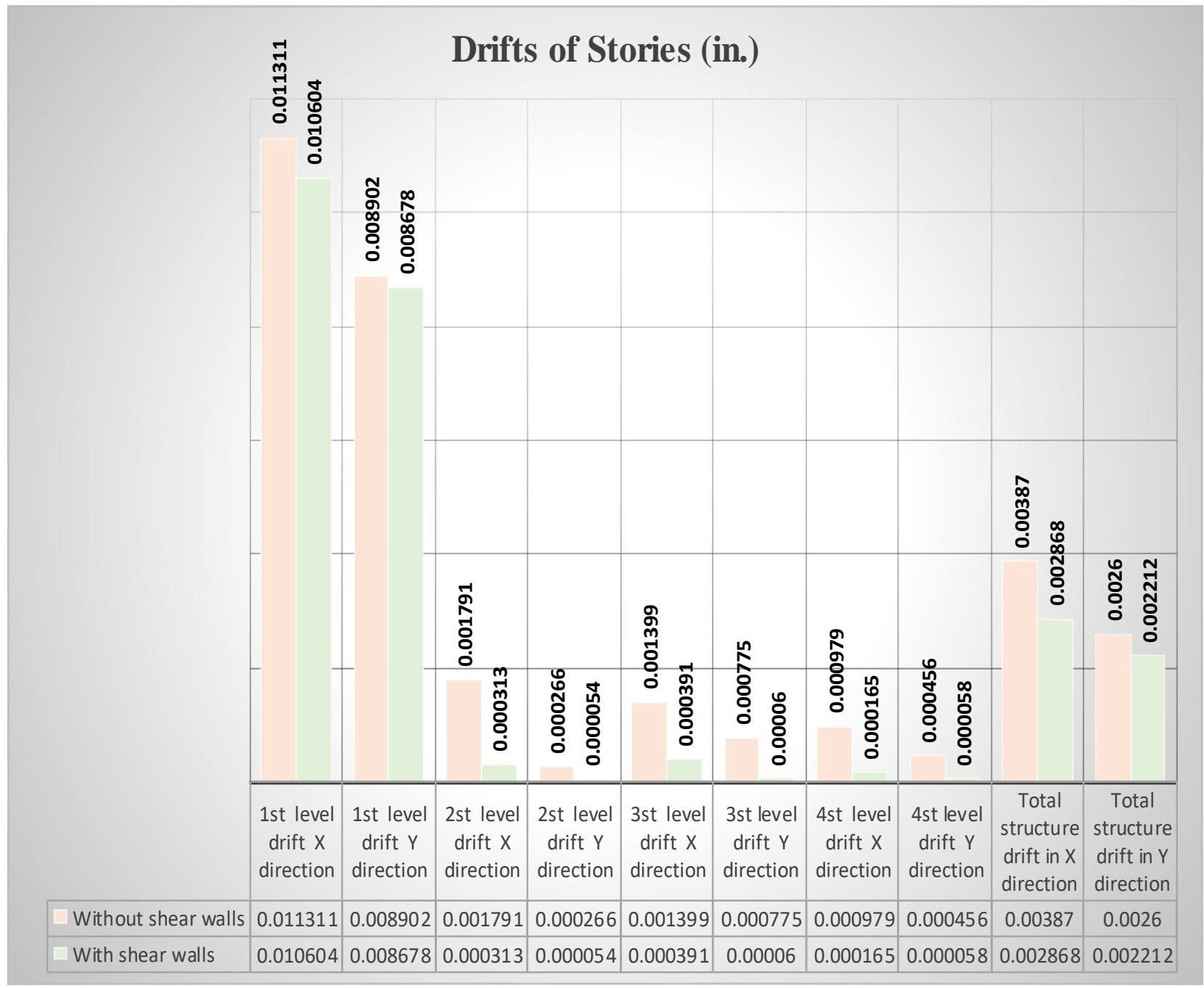

Fig. 15 - Story Drifts

It is clear from the above results that the improvements in the structure seismic resistance and performance are quite beneficial in exchange for the slight increase in the building weight $(7.79 \%$ as shown in Table 7) when the shear walls are added.

\section{CONCLUSION}

This study analyzed a structure with and without any shear walls to determine the effects of shear walls on a building's response to a major earthquake event, the 2002 earthquake in Denali, Alaska. The structural frequency for various modes, design base shear, base moment, and the total weight of the building increased with shear walls, while structural time periods for various modes, maximum story displacements, and story drifts decreased significantly with shear walls. Response modal nonlinear time history analysis most accurately depicted structural behavior.

The results of this study showed that shear walls are necessary to resist lateral loads in a structure. In addition, the use of shear walls significantly reduces the horizontal displacements and drifts.

Nonlinear modal time history analysis, also called Fast Nonlinear Analysis (FNA), is more meticulous and effective than direct integration time history analysis. Numerical values and percent 


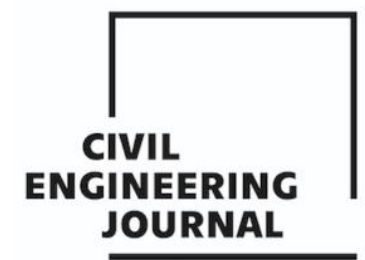

Article no. 60

THE CIVIL ENGINEERING JOURNAL 4-2021

of increase and decrease have been reported in the paper. Results also showed that shear walls significantly affect individual framing members and lead to an increase in column base shear force (up to $45.35 \%$ ) and column base moments (up to 63.56\%), as well as a decrease in horizontal displacements (up to $25.88 \%$ ) and story drifts (up to $92.25 \%$ ). It should be noted that maximum story drifts often govern the design according to most building codes.

\section{REFERENCES}

[1] Felber, Andreas J. 2017. Applied Time History Processing and Interpretation: Strong Motion Record Manipulation for Dynamic Analysis with Tips and Tricks for Data Evaluation. Vancouver, British Columbia:

EDI Experimental Dynamic Investigations, Ltd.

[2] Schueller, Wolfgang. 2009. Building Support Structures: Analysis and Design Using SAP2000

Software. Berkeley, CA: Computer and Structures, Inc.

[3] Bhat M, Shyam, N.A.Premanand Shenoy, and Asha U Rao. 2014. "EARTHQUAKE BEHAVIOUR OF BUILDINGS WITH AND WITHOUT SHEAR WALLS." IOSR Journal of Mechanical and Civil Engineering (IOSR-JMCE) 3: 20-25. https://www.iosrjournals.org/iosr-jmce/papers/ICICE-2014/Volume3/27.\%20147\%20S.pdf.

[4] Chandurkar, P. P., and P. S. Pajgade. 2013. "Seismic Analysis of RCC Building with and Without Shear Wall." International Journal of Modern Engineering Research (IJMER) 3 (3): 1805-10.

http://www.ijmer.com/papers/Vol3 Issue3/DT3318051810.pdf.

[5] Chandana. Kurma, G. S. Vignan, and T. Sai Krishna Teja. 2018. "Non Linear Analysis of Multistoreyed Building with and without Shear Wall." International Journal of Engineering Research And V7 (01). https://doi.org/10.17577/ijertv7is010009.

[6] Tidke, Kiran, Rahul Patil, and G. R. Gandhe. 2016. "Seismic Analysis of Building with and Without Shear Wall." International Journal of Innovative Research in Science, Engineering and Technology 5 (10): 17852-58. https://doi.org/10.15680/IJIRSET.2016.0510080.

[7] Sanjeev, Lokesh. G, Sahebgouda Patil, and Lingaraj Shastri. 2017. "Dynamic Analysis of Multi Storied Building with and without Shear Wall and Bracing." GRD Journals- Global Research and Development Journal for Engineering 2 (9): 44-51. https://www.grdjournals.com/uploads/article/GRDJE/V02/I09/0034/GRDJEV021090034.pdf.

[8] Eberhart-Phillips, D. 2003. "The 2002 Denali Fault Earthquake, Alaska: A Large Magnitude, SlipPartitioned Event." Science 300 (5622): 1113-18. https://doi.org/10.1126/science.1082703.

[9] "2002 M7.9 Denali Fault Earthquake: Alaska Earthquake Center.” n.d. 2002 M7.9 Denali Fault Earthquake | Alaska Earthquake Center. Accessed September 29, 2021.

https://earthquake.alaska.edu/earthquakes/notable/2002-m79-denali-fault-earthquake.

[10] Zad, Nader, and Hani Melhem. 2021. "A Parametric Study on the Effects of Shear Wall Locations in a Typical Five-Story Reinforced Concrete Structure Subjected to a Severe Earthquake." Current Trends in Civil \& Structural Engineering 7 (5): 1-15. https://doi.org/10.33552/CTCSE.2021.07.000675. 